\title{
景色構成要素が居間の空の視環境関連機能に対する評価に与える影響 THE EFFECT OF VIEW COMPONENTS ON EVALUATION FOR FACULTIES RELATED TO VISUAL ENVIRONMENT IN FAMILY ROOM
}

\author{
奥田紫乃*, 佐藤隆二** \\ Shino OKUDA and Ryuji SATOH
}

\begin{abstract}
This study aims to clear the effect of view components on evaluation for window faculties related to visual environment in family room. It is assumed that the ultimate evaluation for window in family room consists of five faculties; "day-lighting", "visibility of view", "comprehensibility of outside", "part of interior", and "protection of privacy". Furthermore, it was extracted five view components; 'sky', 'ground', 'wall', 'window', and 'green'. In order to examine the effect of each area rate of view components on the evaluation for each window faculty and ultimate evaluation, a subjective evaluation experiment was carried out. It was shown that the evaluation of each window faculty was related to one or more view components.
\end{abstract}

Keywords : window, view component, area rate, regression analysis 空, 景色構成要素, 面積比率，回帰分析

\section{1. はじめに}

空は、居住空間において必要不可欠な存在であり、様々な要求が 課せられる存在である。一般に空とは、採光または通風の目的で、 壁または屋根にあけた開口部とされている ${ }^{1)}$ 。しかし、今日の空の 設計・計画においては、採光, 通風, 換気, 眺望などを目的とし、 日常の人の出入りには供さない開口部である ${ }^{2)}$ との位置づけの下、 その位置や大きさが決定されている。建築基準法では、空の役割は 主に採光と換気であるとされ、採光のためには、床面積の $1 / 7$ 以上 の面積をもつ空が必要であると規定されているが、2000 年に採光補 正係数が導入されたことで、条件によっては開口率が $1 / 7$ を下回る 空も法律的に許容されているのが現状である。この" $1 / 7 "$ という基 準值は、約半数の居住者が採光に対して満足と感じる值であるもの の、採光に対する満足が得られる開口率は、戸建住宅か集合住宅か、 高層階か低層階かなどの住宅タイプの違いや、室の使用目的によっ て異なる傾向がみられる ${ }^{3)}$ 。

空の主たる機能が採光であることを前提として、昼光により明る さを確保したり、屋外が見えることにより開放感が得られることに ついては、様々な側面から研究が行われている $\left.{ }^{4)} \sim 10\right)$ 。しか、居 住者が空に求める機能は、採光のほかにも採暖（熱の流入）、空気 の流出入 (換気)、人の出入り（日常／非日常）、視情報の獲得など
も必要であり ${ }^{1112)}$ 、「天候を観察できる」「時間の経過がわかる」こ とに対する要求は、外界との心理的な繋がりを潜在的に求める意識 の表れであるとされている ${ }^{13)}$ 。一方、実生活においては、状況に応 じて外部とのつながりを遮断したいという要求も生じるため、居住 者はカーテンやブラインド、ロールスクリーンなどの空装備を用い て、室内の視覚情報の流出を調整している ${ }^{14)}$ 。したがって、これら の双方向性にも配慮しながら、様々な機能が満たされるような窓の 設計指針が示されることが理想的である。

図 1 に、空の視環境関連機能の評価に影響する諸要因を示す。空 の視環境関連機能に影響するものとして、空材や空装備などの窓に 関連する要因や、空周辺の室内壁面などの室内環境要因、年齢や性

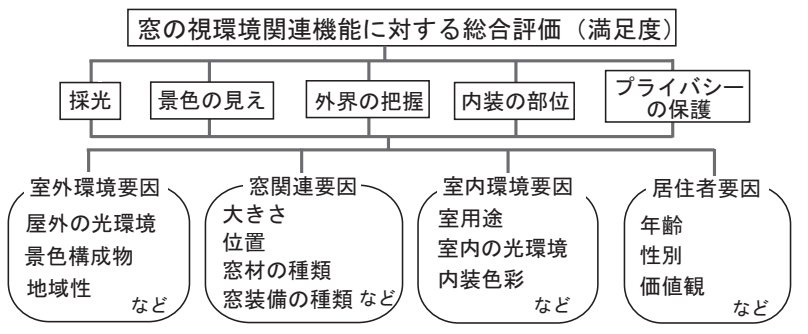

図 1 空の視環境関連機能に関する評価に影響する要因

\footnotetext{
本稿は2006，2007年の日本建築学会大会 ${ }^{15} 1$ 16)，及び2005年の照明学会全国大会 ${ }^{17)}$ において発表したものをまとめ，再構成したものである。

* 同志社女子大学生活科学部人間生活学科 講師・博士(工学) Lecturer, Dept. of Human Life Studies, Fac. of Human Life Science, Doshisha Women's

** 大阪工業大学工学部建築学科 教授 $\cdot$ 工博 College of Liberal Arts, Dr. Eng. Prof., Dept. of Architecture, Faculty of Engineering, Osaka Institute of Technology, Dr. Eng.
} 
別、価值観などの居住者の要因、さらに空の向こう側にある屋外環 境要因が挙げられる。屋外環境要因の一つである景色構成物につい て、宮代らは草・木や山などは好まれる要素、建物や高速道路など は嫌われる要素であると報告している ${ }^{18)}$ 。また、丸橋らは隣棟間隔 が大きい外景条件下において、悹の 5 つの役割評価（景色の見え・ 外界情報の獲得・室内外の移動・プライバシー保持）が高く、内装 の部位評価における「落ち着き・気分転換」の評価が高いと報告し ている ${ }^{19) 20)}$ 。石川らは隣接する住宅棟の高さが低く、空遮蔽率が低 い条件下で満足度が高いことや、水平面が見える条件において満足 度が高いことを明らかにしている ${ }^{21)}$ 。れれらの研究では、評価を左 右する外景の内容を客観的に表現することなく、外景の局部に着目 した事例的知見が示されているため、それらの知見を普遍的な計画 で活用することが困難である。

これらを踏まえ、本研究では先行研究の結果 ${ }^{22)}$ ２5) に基づき、室 内外の視線の双方向性を考慮して空の視環境関連機能を「採光」「景 色の見え」「外界の把握」「内装の部位」「プライバシーの保護」の 5 つの機能に集約し、景色の構成要素が空の視環境関連機能に対す る評価に影響を及ぼす程度を明らかにすることを目的とした主観評 価実験を行った。なお評価対象となる景色構成においては、視環境 関連機能の評価における主要な説明変量が、景色構成要素の面積比 率であると仮定して検討を進めることとした。検討に先立ち、景色 構成要素の種類及び面積比率が住宅タイプにより異なることに配慮 し、本研究では戸建住宅を対象として空から見える景色構成要素の 抽出を行った結果について次章に述べる。

表 2 景色条件画像（対面住宅）

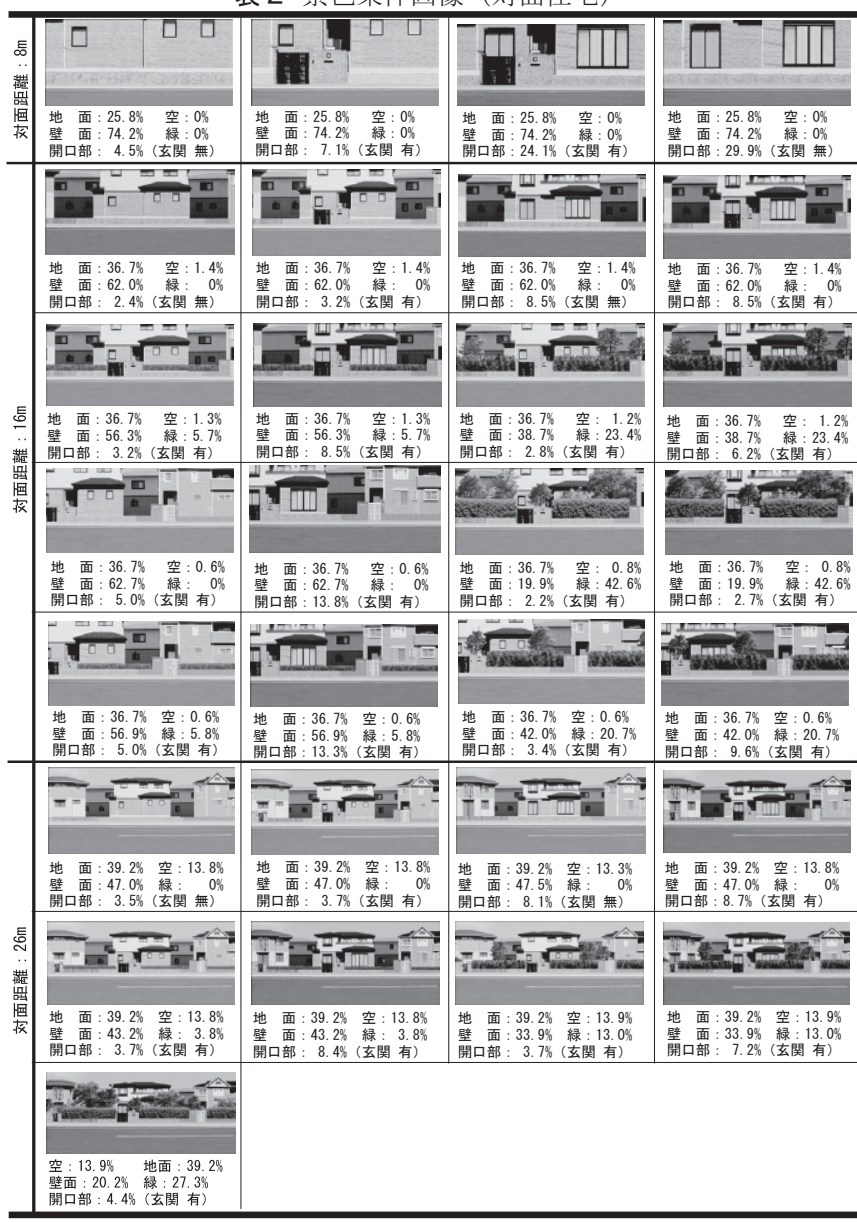

\section{2. 言外の景色構成要素}

主観評価実験に先立ち、戸建住宅の空から見える景色構成要素を 抽出することを目的として、空から見える景色の構成要素に関する 実態調查を行った。調査においては、戸建住宅が数多く立ち並ぶ住 宅地において 302 枚の景色写真を撮影し、景色構成要素の抽出・分 類を試みた。これらの写真を概観した結果、住宅地における一住戸 の空から見える景色は、対面住宅または隣接住宅の壁面が含まれる ことがほとんどであり、住宅壁面までの距離により、空や地面など が見える割合が異なることが明らかとなった。また、住宅壁面にあ る空や玄関、公園や庭、街路にある樹木・植栽、電柱や看板、道路 標識などの人工工作物のほか、写真撮影時に通行している人や自転 車、自動車などの路上移動物なども抽出された。空の視環境関連機 能に対する評価への影響要因としての景色構成要素を抽出すること が前提であることから、看板・標識などの人工工作物や通行人など の非定常物を除外して、表 1 に示寸要素を空外の景色構成要素とし て抽出した。即ち、対面または隣接する住宅壁面までの距離により その面積割合が変動する『空』『地面』『壁面』、住宅壁面に存在する空・ 立関である『開口部』、樹木や植栽である『緑』の 5 要素である。

本研究では、空から見える景色の構成要素としてこれらの 5 要素 を選定し、各構成要素の面積比率が異なる景色条件を設定して、空 の視環境関連機能に関する評価との関連について検討することを目 的として主観評価実験を行った。

3. 空の視環境関連機能に関する主観評価実験の概要

3.1 空から見える景色条件画像の作成

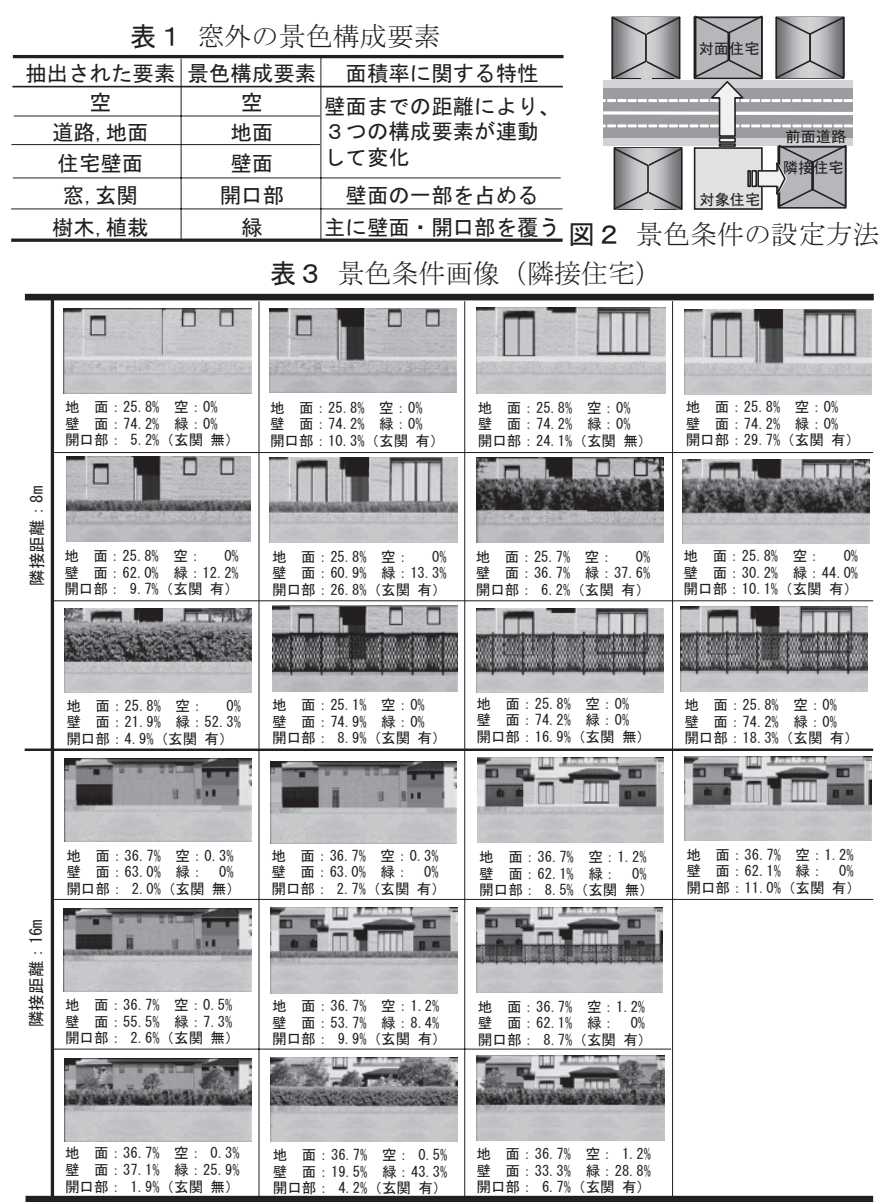


本実験では、『空』『地面』『壁面（壁面にある開口部を含む）』『開 口部』『緑』を景色構成要素とし、戸建住宅を中心とした住宅地に おいて、不都合がない範囲内でこれらの面積比率が広範囲に渡るよ うに配慮しながら景色条件画像の作成を行った。これらの景色の様 相は季節や天候により異なるものであるが、本実験では夏の晴天時 における景色を想定して条件画像を作成した。図 2 に景色条件の設 定方法を示す。空から見える周辺住宅の壁面が、対象住宅と道路を 挟んで向かい合わせる対面住宅、及び対象住宅に隣り合わせる隣接 住宅の 2 種類を設定し、それぞれ $8 \mathrm{~m} 、 16 \mathrm{~m} 、 26 \mathrm{~m}$ の 3 種の距離条件 を設定した。また、空の大きさについて 2 条件、玄関の有無につい て 2 条件、植栽の量について 3 条件を設定し、対面住宅においては、 対面する住宅が対象住宅の真向い、及び斜め向いに位置する条件の 2 条件を設定した。表 2 に対面住宅の景色条件画像、表 3 に隣接住 宅の景色条件画像を示す。対面/隣接壁面までの距離の違いにより 面積比率が異なる『空』『地面』『壁面』のほか、住宅壁面に玄関を 設置したり空の大きさを変化させることで『開口部』の面積比率を、 宅地周りの植栽の量を変化させることで『緑』の面積比率を変化さ せ、計 51 条件の景色条件画像を作成した。

\section{2 実験装置の概要}

実験には、室の一外壁面の空構成が取り替え可能である住宅の居 間空間の縮尺模型、及び室外の景色を空面に投影できる装置から成 る図 3 に示寸装置を使用した。図 4 に景色条件画像を投影した際の 縮尺模型内部の様子（観察視点とは異なる）を示す。縮尺模型は、 $4 \mathrm{~m} \times 5 \mathrm{~m} \times 2.3 \mathrm{~m}$ の居間空間を約 $1 / 6.2$ 亿縮尺したものであり、天井面 と室内壁面をN9 のクロス材、床面をカーペットを模擬した N6. 5 の 無光沢仕上げとし、N6 のソファー、及びN4 のテーブル・テレビ・ テレビボードを室内に配置したものである。また、空をもつ壁面は、 透明アクリル板に空以外の壁部分をN9 の画用紙で覆ったパネルで 製作し、掃き出し空 4 枚分の $910 \mathrm{~mm} \times 1820 \mathrm{~mm}$ 開口部を設けた。

\section{3 実験方法}

図 3 に示寸透過式スクリーンに、3.1 節で述べた 51 種類の景色条 件画像を順不同に投影し、視線を床面高さ約 $1 \mathrm{~m}$ に固定した条件で 空及び空から見える景色を観察させて、「採光」「景色の見え」「外 界の把握」「内装の部位」「プライバシーの保護」の空の視環境関連

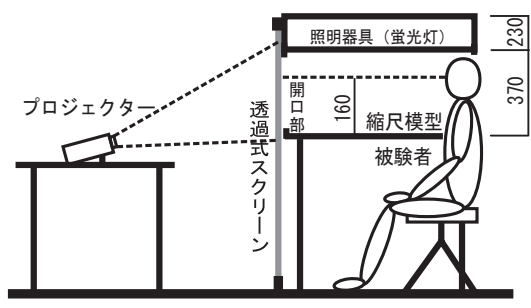

図 3 実験装置

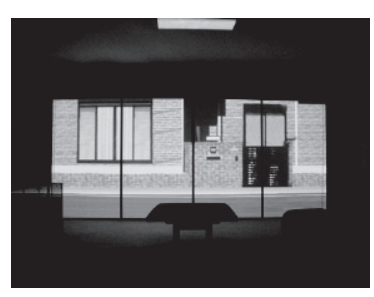

図 4 縮尺模型内部

表 4 空の視環境関連機能と各機能評価における言語評価尺度

\begin{tabular}{|c|c|c|c|c|c|c|}
\hline & 採光 & 景色の見え & 外界の把握 & 内装の部位 & 外部の視線 & 総合評価 \\
\hline & $\begin{array}{l}\text { この空から採光 } \\
\text { 光得られると感 } \\
\text { じられる程度は } \\
\text { どうですか }\end{array}$ & $\begin{array}{l}\text { この空から外が } \\
\text { 見える程度はどう } \\
\text { ですか }\end{array}$ & $\begin{array}{l}\text { この窓から天候 } \\
\text { ·季節・時刻な } \\
\text { ごの外界の様子 } \\
\text { を把握する程度 } \\
\text { はどうですか }\end{array}$ & $\begin{array}{l}\text { この景色を含む空の } \\
\text { 室内仕上げの一部と } \\
\text { しての好ましさの程 } \\
\text { 度はどうですか }\end{array}$ & $\begin{array}{l}\text { この㝕を通して } \\
\text { 外部からの視線 } \\
\text { を感じる程度は } \\
\text { どうですか }\end{array}$ & 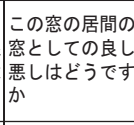 \\
\hline & $\begin{array}{l}\text { 非常に多い } \\
\text { 多い } \\
\text { やや多い } \\
\text { やや少ない } \\
\text { 少ない } \\
\text { 全くない }\end{array}$ & 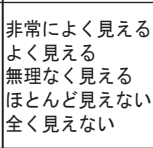 & 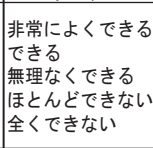 & \begin{tabular}{|l|} 
非常に好ましい \\
好ましい \\
やや好ましい \\
あまり好ましくない \\
全く好ましくない
\end{tabular} & $\begin{array}{l}\text { 全く感じない } \\
\text { あまり感じない } \\
\text { やや感じる } \\
\text { 感じる } \\
\text { 非常に感じる }\end{array}$ & $\begin{array}{l}\text { 非常に良い } \\
\text { 良い } \\
\text { どちらでもない } \\
\text { 悪い } \\
\text { 非常に悪い }\end{array}$ \\
\hline
\end{tabular}

機能、及びそれらを統合した「総合評価」について、言語評価尺度 を用いて評価させた。表 4 に各視環境関連機能ごとの具体的な質問 内容と言語評価尺度を示す。なお、「プライバシーの保護」につい ては、外部からの視線を感じる程度で評価させることとし、以後は 「外部の視線」と表現する。なお、各景色条件画像を提示した場合 の模型中央部における水平面照度は 151 ～1901x、平均值で $1671 \mathrm{x}$ であり、条件提示順序による評価への影響は無いものとした。実験 は、大阪工業大学環境工学実験室で行い、20 代の大阪工業大学の学 生 12 名に対して、一人につき 3 回ずつ、片眼視で評価を行わせた。

\section{4. 各景色条件下における空の諸機能に対する評価結果}

本実験で設定した 51 種の景色画像条件において、6 種の評価項 目に対する計 36 回の評価を得た。これらの評価結果を概観すると、 各条件下における各評価項目に対する 36 個の評価結果の標準偏差 は、そのほとんどが 1.0 以下であり、最大で 1.1 であった。本研究 では、景色構成要素が空の視環境関連機能に与える影響について、 評価結果全体の定性的な傾向の把握を主眼に置き、得られた評価結 果の代表值である平均值を用いて検討を行った。

表 5 に、対面住宅条件における対面住宅までの距離、及び景色 構成要素『緑』の量と評価結果との関係を各視環境関連機能ごとに 示す。「外部の視線」を除く 4 種の機能評価及び総合評価において、 対面住宅までの距離が大きいほど空機能に対する評価が高い傾向が みられ、外部の視線においては、距離が小さいほど視線を感じる程

表 5 景色条件画像ごとの各種空機能評価結果（対面住宅）

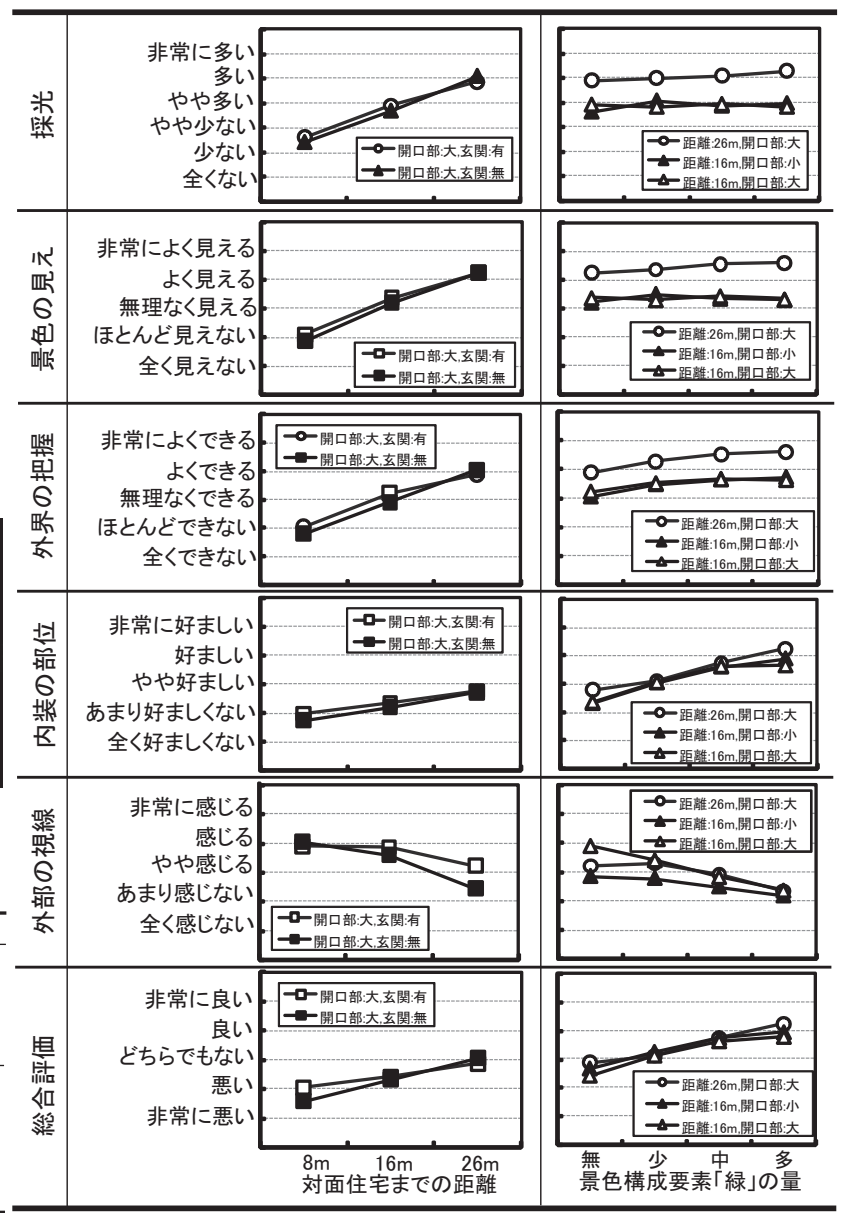


度が大きい傾向がみられる。また、玄関の有無による評価への影響 はほとんどみられないことから、空と玄関を併せて『開口部』とし て取り扱うことに支障がないことが確認できる。「外界の把握」「「内 装の部位」及び「総合評価」においては、『緑』の量が多いほど評 価が高い傾向がみられ、「外部の視線」においては、『緑』の量が多 いほど外部の視線を感じない傾向がみられる。これは、『緑』が多 い景色条件は、植栽が対面住宅壁面の空を覆い隠している条件であ るため、景色構成要素の『開口部』が小さいことが影響していると 推察される。また、「採光」、「景色の見え」、「外界の把握」及び「総 合評価」においては、対面住宅までの距離が大きいほど評価が高い が、『開口部』の大小は評価にほとんど影響しない傾向が読み取れる。

以上の結果より、空の各視環境関連機能に対する評価および総合 評価は、対面及び隣接住宅までの距離に大きく左右されることから、 住宅までの距離が異なることにより、『空』、『地面』、『壁面』の面 積比率が異なることが、空の視環境関連機能に対する評価に影響し ていることが示唆された。また、景色構成要素の『緑』や『開口部』 の量に影響を受ける視環境関連機能が存在することも示された。こ れらの知見に基づき、各景色条件画像における 5 種の景色構成要素 と各種評価との関連性について次章に述べる。なお、本研究では空
の設計計画時に空外の景色を簡易に組み込むことが目標であること から、景色構成要素の面積比率を用いて検討を行うこととする。

5. 景色構成要素が空の視環境関連機能に関する評価に及ぼす影響 5.1 各景色構成要素の面積比率と視環境関連機能との関係

本実験で用いた景色条件画像は、対面/隣接する住宅までの距離 や植栽配置などにより、『空』や『緑』がない条件が存在するため、 面積比率に偏りのある変数も存在しているが、先ずは全ての景色構 成要素と各視環境関連機能に対する評価との関係を概観することを 目的として、単回帰分析を行った。表 6 に、「採光」「景色の見え」「外 界の把握」「内装の部位」「外部の視線」の各視環境関連機能に関す る評価、及び「総合評価」に対する評価結果の平均值と、『空』『地面』 『壁面』『開口部』『緑』の面積比率との相関、単回帰式、相関係数 $(r)$ 、 及び有意確率（両側）(p) を示す。

「採光」に対する評価では、、空』の面積比率との相関係数が 0.80 、 『地面』の面積率との相関係数が 0.91 であることから、「採光」は『空』 及び『地面』との関連性が強いといえる。

「景色の見え」に対する評価では、『空』の面積比率との相関係数 が 0.76、『地面』の面積比率との相関係数が 0.94 であることから、

表 6 景色構成要素の面積比率と各種空関連機能評価結果の関連性

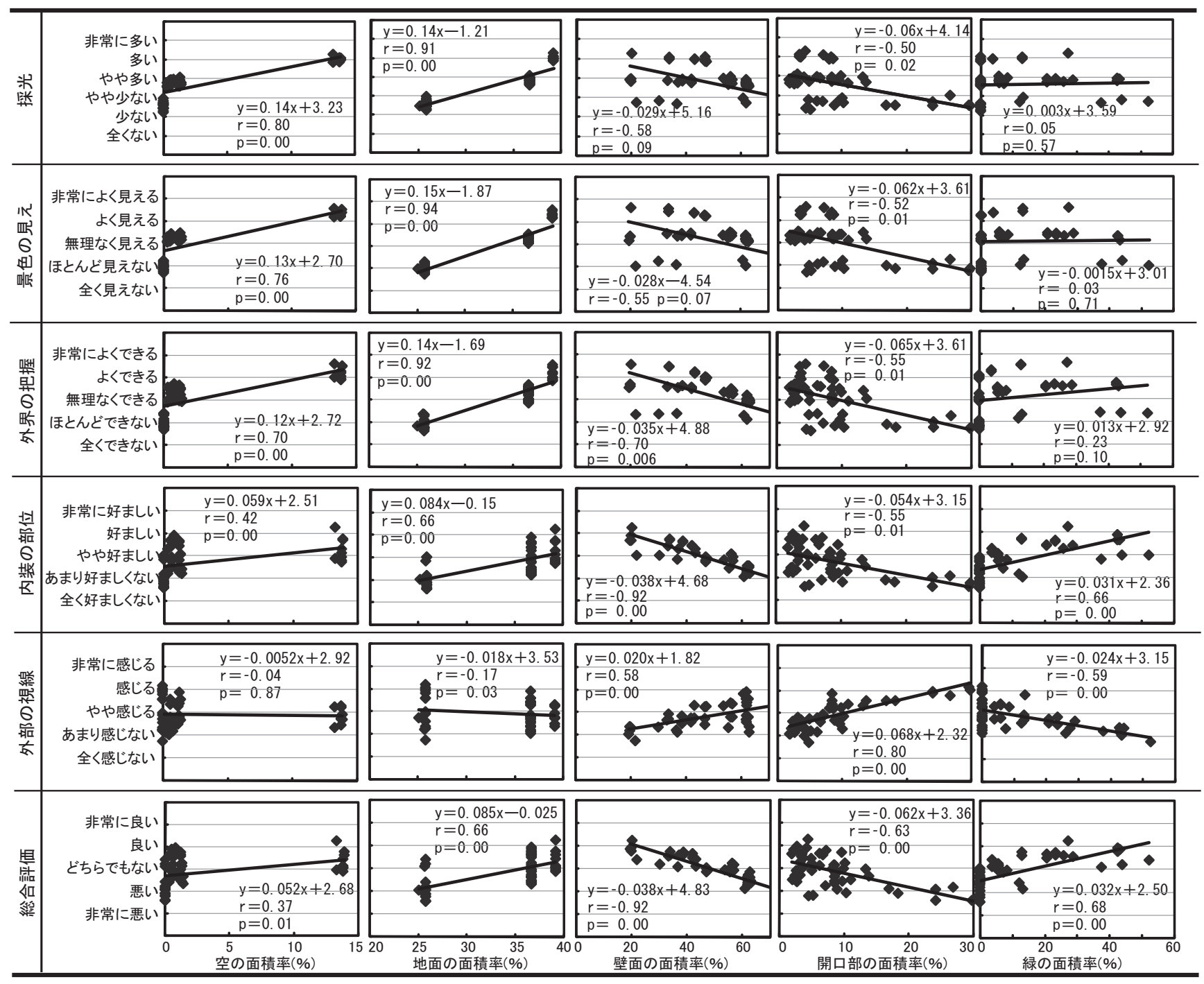


表 7 景色構成要素の面積比率と空の視環境関連機能に関する評価との重回帰分析結果

\begin{tabular}{|c|c|c|c|c|c|c|c|c|c|c|c|c|}
\hline \multirow{2}{*}{$\begin{array}{c}\text { 景色 } \\
\text { 構成要素 }\end{array}$} & \multicolumn{2}{|c|}{ 採光 $\quad\left(R^{2}=0.984\right)$} & \multirow{2}{*}{$\begin{array}{l}\text { 景色の見え } \\
\text { 標淮回帰係数 }\end{array}$} & \multirow{2}{*}{$\begin{array}{l}\left(\mathrm{R}^{2}=0.98\right. \\
\text { 有意確率 }\end{array}$} & \multirow{2}{*}{ 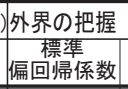 } & \multirow{2}{*}{$\begin{array}{l}\left(\mathrm{R}^{2}=0.975\right) \\
\text { 有意確率 }\end{array}$} & \multicolumn{2}{|c|}{ 内装の部位 $\left(\mathrm{R}^{2}=0.918\right)$} & \multicolumn{2}{|l|}{ 外部の視線 } & \multicolumn{2}{|c|}{ 総合評価 $\left(R^{2}=0.938\right)$} \\
\hline & $\begin{array}{l}\text { 標隻 } \\
\text { 晋回㷌係数 }\end{array}$ & 有意確率 & & & & & $\begin{array}{c}\text { 標隻 } \\
\text { 偏回㷌係数 }\end{array}$ & 有意確率 & $\begin{array}{c}\text { 標隻 } \\
\text { 偏回帰係数 } \\
\end{array}$ & 有意確率 & 楄回㷌係数 & 有意確率 \\
\hline 空 & 0.369 & 0.000 & 0.262 & 0.000 & 0.234 & 0.000 & 0.186 & 0.003 & 0.000 & 0.996 & 0.143 & 0.009 \\
\hline 地面 & 0.763 & 000 & 0.810 & & & & 0.630 & & 0.530 & 000 & 630 & 000 \\
\hline 壁面 & -0.076 & 0.055 & -0.232 & & -0.244 & 0.000 & -0.031 & & 0.241 & 0.022 & 0.058 & 0.454 \\
\hline 開口部 & 031 & & 0.017 & & 0.028 & & 0.006 & & 0.752 & 0.000 & -0.097 & 0.038 \\
\hline 緑 & 0.041 & 0.231 & -0.120 & 0.001 & 0.051 & 0.237 & 0.592 & 0.000 & -0.085 & 0.336 & 0.640 & 0.000 \\
\hline
\end{tabular}

「採光」と同様に、「景色の見え」も『空』及び『地面』との関連性 が強いといえる。これより、空外の近い位置に建物などの視界を遮 るものがなく、空前が開けていることが、「採光」及び「景色の見え」 に対する高評価を得るために必要な条件であることがわかる。

「外界の把握」に対する評価では、『空』の面積率との相関係数が 0.70 、『地面』の面積率との相関係数が 0.92 、『壁面』の面積率との 相関係数が -0.70 であることから、「外界の把握」は『空』『地面』 及び『壁面』との関連性が比較的強いことがわかる。また、『壁面』 の面積率とは負の相関であることから、空外の景色の中で人工物で ある『壁面』の面積が大きいほど、時節や天候など外界の様子が把 握しづらくなることが窥える。

「内装の部位」に対する評価では、『壁面』の面積比率との相関係 数が -0.92 であることから、「内装の部位」は『壁面』との関連性 が極めて強いことがわかる。『壁面』の面積比率とは負の相関であ り、即ち空外の景色の中で人工物である『壁面』の面積が大きいほ ど、「内装の部位」が悪くなることが推察される。また、『緑』の面 積比率との相関係数が 0.66 であることから、「内装の部位」は『緑』 との関連性があることが示唆されている。

「外部の視線」に対する評価では、『開口部』の面積比率との相関 係数が 0.80 であることから、「外部の視線」は『開口部』との関連 性が強いことがわかる。近隣住宅内にいる人の視線に対して、プラ イバシーが侵されると感じる傾向が読み取れる。

「総合評価」に対する評価では、『壁面』の面積比率との相関係数 が -0.92 と高い值であると同時に、『地面』『開口部』『緑』の面積 比率との相関係数もそれぞれ $0.66 、-0.63 、 0.68$ であることから、 これらの構成要素との関連性も示唆されている。

以上の結果より、空の各視環境関連機能に対する評価ごとに、関 連性の高い景色構成要素が 1 種または複数存在することが確認でき た。

\section{2 景色構成要素が視環境関連機能に関する評価に与える影響の} 程度

空の各視環境関連機能に対する評価ごとに景色構成要素の関連性 の強さの程度を明らかにするため、『空』『地面』『壁面』『開口部』『緑』 の各構成要素の面積比率を説明变数、「採光」「景色の見え」「外界 の把握」「内装の部位」「外部の視線」を目的変数として重回帰分析 を行った。本実験における景色画像条件においては、構成要素の面 積比率が相対的に変化するものも含まれるが、本論文では外景を構 成する 5 つの景色構成要素と各視環境関連機能に対する評価との関 連性について検討することが妥当であると考え、全ての景色構成要 素を説明変数として分析を行った。分析において、視環境関連機能 ごとに異なる数の言語評価尺度を用いていることに配慮し、視環境
関連機能に関する各評価結果を 100 点満点に換算した。表 7 に、標 準偏回帰係数、及び有意確率を示し、有意確立 $5 \%$ 未満のものを逆 対比で表記する。

「採光」では、『空』及び『地面』の有意確率が $5 \%$ 未満であるこ とから、『空』と『地面』の面積比率が評価に影響していることが わかる。また、これらの標準偏回帰係数值から『空』より『地面』 の面積比率に影響を受けることが示された。

「景色の見え」では、『空』、『地面』、『壁面』及び『緑』の有意 確率が $5 \%$ 未満であることから、『空』、『地面』、『壁面』及び『緑』 の面積比率が評価に影響していることがわかる。また、『地面』に おける標準偏回帰係数が最大であることから、『地面』の面積比率 に最も影響を受けることが示された。

「外界の把握」では、『空』、地面』及び『壁面』の有意確率が $5 \%$ 未満であることから、『空』、地面』及び『壁面』の面積比率が評 価に影響していることがわかる。また、『地面』における標準偏回 帰係数值が最大であることから、『地面』の面積比率に最も影響を 受けることが示された。

「内装の部位」では、『空』、『地面』及び『緑』の有意確率が $5 \%$ 未満であることから、『空』、『地面』及び『緑』の面積比率が評価 に影響していることがわかる。また、『地面』と『緑』の標準偏回 帰係数がほぼ同值で最大であることから、『緑』と『地面』の面積 比率に大きく影響を受けることが示された。

「外部の視線」では、『地面』、『壁面』及び『開口部』の有意確率 が $5 \%$ 未満であることから、『地面』、『壁面』及び『開口部』の面 積比率が評価に影響していることがわかる。また、『開口部』の標 準偏回帰係数值が最大であることから、『開口部』の面積比率に大 きく影響を受けることが示された。

「総合評価」では、『壁面』を除く 4 種の景色構成要素における有 意確率が $5 \%$ 未満であることから、『空』、『地面』、『開口部』、及び 『緑』の面積比率が総合評価に影響していることがわかる。また、「内 装の部位」における結果と同様に、『地面』と『緑』の標準偏回帰 係数がほぼ同值で最大であることから、『緑』と『地面』の面積比 率に大きく影響を受けることが示された。

以上の結果より、空の視環境関連機能ごとに、評価に影響を及ぼ 寸景色構成要素は異なることが示された。また、『地面』は全ての 視環境関連機能に関する評価に、『空』は「外部の視線」を除く全 ての視環境関連機能に関する評価に影響していることから、対面 / 隣接する住宅壁面までの距離が空の評価に大きく影響することが示 された。

\section{6. おわりに}


本稿では、空を評価する際に、空と空から見える景色は切り離せ ないとの考えの下、空の視環境関連機能を「採光」「景色の見え」「外 界の把握」「内装の部位」「プライバシーの保護」に集約して、空か ら見える景色の構成要素の面積比率が空の諸機能に対する評価に与 える影響について主観評価実験を行った結果について検討した。そ の結果、空の各視環境関連機能に対する評価ごとに、関連性の高い 景色構成要素が 1 種または複数存在すること、対面または隣接する 住宅壁面までの距離が空の評価に大きく影響することが示された。 しかし、本実験装置では実際に屋外の光環境を疑似させているわけ でなく、景色画像から採光が得られると感じられるかを対象として いるため、今後は実際の光量のバランスにも配慮した上でさらに検 討する必要がある。

\section{謝辞}

本研究の遂行において、当時大阪工業大学卒業研究生の荒井清香 氏、村田有美子氏、廣田実希子氏、田村愛氏、細川まりこ氏、斎藤 早紀子氏、辻野祐二氏、仲真良氏の協力を得ました。ここに記して 謝意を表します。

\section{参考文献}

1）広辞苑 第 6 版 新村出編，岩波書店，2008.1

2）建築学用語辞典. 第 2 版 日本建築学会編，岩波書店， 1999.9

3）宗方淳、平手小太郎、井上容子、大井尚行、佐藤隆二：住宅居室の採光 満足度に関する研究，日本建築学会環境系論文集 第 590 号, p p. 17-22, 2005. 4

4）宮田紀元 : 住宅の空の大きさに関する主観実験（居間の場合), 日本建築 学会大会学術講演梗概集, pp. 59-60, 1982.10

5）乾正雄、宮田紀元、渡辺圭子：開放感に関寸る研究・ 1 , 日本建築学会 論文報告集 第 192 号, pp. 49-55，1972. 2

6）乾正雄、宮田紀元、渡辺圭子：開放感に関する研究・ 2 , 日本建築学会 論文報告集 第 193 号, pp. 51-57, 1972.3

7）乾正雄、宮田紀元、渡辺圭子：開放感に関寸る研究・ 3 , 日本建築学会 論文報告集 第 194 号, pp. 39-44，1972.4

8）中村芳樹、小林茂雄、乾正雄、近藤友洋、大沢正嗣: 空面に装着するスクリー ンの輝度抑制性能と景観透視性能, 日本建築学会計画系論文集 第 484 号, pp. 9-16, 1996. 6

9）伊藤大輔、岩田利枝 : ブラインドを通してみる眺望に対する在室者の満 足度にブラインドと屋外の輝度比が与える影響、日本建築学会環境系論 文集 第 622 号, pp. 17-23，2007. 12

10）原直也：空外に景色を有する室の明るさに基づく種々の明るさ指標の有
効性の検討, 日本建築学会環境系論文集 第 615 号, pp. 9-14, 2007.5

11）佐藤隆二、佐藤真奈美 : 住宅の居間空間における空の実態と居住者の空 に対する意識に関する調査研究, 日本建築学会大会学術講演梗概集 D-1, pp. $755-756,2000.9$

12）佐藤隆二、佐藤真奈美 : 住宅の居間空間における空の諸機能に対する居住 者の要 - 不要意識, 日本建築学会大会学術講演梗概集 D-1, pp. 405-406, 2002.8

13）松原斎樹、藏澄美仁、西田優花、磯野千都、下村 孝 : 京都市内の大学の 学生を対象とした空の心理的効果に関する調査研究, 日本建築学会技術報 告集 第 10 号, pp. 169-172，2000.6

14）奥田紫乃、佐藤隆二：外部からの視線に対する居住者の意識と空及び周辺 環境の実態，照明学会誌 第 89 巻 第 2 号, pp. 77-82, 2005.2

15）奥田紫乃、佐藤隆二：住宅の居間の空における視環境に関連する役割に関 寸る基礎研究 一その 3 . 景色構成要素の面積比率が評価に与える影響一, 日本建築学会大会学術講演梗概集 D-1，pp. 301-302，2006.9

16）奥田紫乃、佐藤隆二：住宅の居間の空における視環境に関連する役割に関 寸る基礎研究 一その 4 . 景色構成要素の面積比率に基づく各種評価の予 測式一, 日本建築学会大会学術講演梗概集 D-1, pp. 435-436, 2007.8

17) 奥田紫乃、佐藤隆二：住宅の居間の空における視環境に関連する役割に関 する基礎研究 その 3 . 景色の構成要素が評価に与える影響, 平成 17 年度 照明学会第 38 回全国大会学術口演梗概集, pp. 115-116, 2004.8

18）宮代豪、会田朋子、乾正雄 : 高層集合住宅における空外の景色の評価, 日 本建築学会大会学術講演梗概集 計画系, pp. 321-322, 1983.9

19）丸橋靖明、山中俊夫、甲谷寿史 : 集合住宅の居間における空の役割・印象・ 満足度に関する主観評価, 日本建築学会近畿支部研究報告集 環境系第 41 号、pp. 121-124，2001.6

20）丸橋靖明、山中俊夫、甲谷寿史 : 集合住宅の居間における空の役割・印象・ 満足度に関する主観評価（その 2) 空の満足度と空に対する諸評価の関連 性, 日本建築学会大会学術講演梗概集 D-1, pp. 793-794, 2001.9

21）石川愛、鈴木広隆：居間の満足度に影響を与える空を通した外景構成要 素についての研究, 日本建築学会大会学術講演梗概集 F-1, pp.979-980, 2001.9

22）奥田紫乃、佐藤隆二 : 住宅の居間の空における視環境に関連する役割に関 する基礎研究 一その 1 .「採光」および「景色の見え」に関する評価結果 一, 日本建築学会大会学術講演梗概集 D-1, pp. 407-408, 2004. 8

23) 佐藤隆二、奥田紫乃：住宅の居間の空における視環境に関連する役割に関 寸る基礎研究 一その 2 .「外界の把握」「室の印象」および「外部の視線」 に関する評価結果一, 日本建築学会大会学術講演梗概集 D-1, pp. 409410, 2004. 8

24）奥田紫乃、佐藤隆二：住宅の居間の空における視環境に関連する役割に関 する基礎研究 その 1 . 空の大きさ・配置が空の評価に及ぼす影響, 平成 16 年度照明学会第 37 回全国大会学術口演梗概集, pp. 115-116, 2004. 8

25）佐藤隆二、奥田紫乃：住宅の居間の空における視環境に関連する役割に関 する基礎研究 その 2 . 景色の種類・距離が空の評価に及ぼす影響, 平成 16 年度照明学会第 37 回全国大会学術口演梗概集, pp. 117-118, 2004.8 